\title{
Prevalence of Equine Gastric Ulceration in Standardbred Racehorses in Czech Republic
}

\author{
B. BEZDĚKOVÁ ${ }^{1}$, P. JAHN ${ }^{1}$, M. VYSKOČIL ${ }^{2}$, J. PLACHÝ 3 \\ ${ }^{1}$ Department of Internal Medicine, Horse Clinic, Faculty of Veterinary Medicine \\ ${ }^{2}$ Institute of genetics, Faculty of Veterinary Medicine \\ ${ }^{3}$ Department of Surgery and Orthopaedics, Horse Clinic, Faculty of Veterinary Medicine University \\ of Veterinary and Pharmaceutical Sciences, Brno, Czech Republic \\ Received September 6, 2004 \\ Accepted March 3, 2005
}

\begin{abstract}
Bezděková, B., P. Jahn, M. Vyskočil, J. Plachý: Prevalence of Equine Gastric Ulceration in Standardbred Racehorses in Czech Republic. Acta Vet. Brno 2005, 74: 59-65.

The objective of our study was to determine an association between age, sex and prevalence and severity of gastric ulceration in Standardbred racehorses in training in Czech Republic. Alltogether 54 Standardbred racehorses were used in our study. History was taken and subsequently gastroscopy was performed in each horse. Mucosal ulceration was evaluated using grading system ranging from 0 (normal mucosa, no lesions) to 4 (diffuse ulceration of mucosa, loss of margo plicatus continuity, with or without haemorrhage). Correlation between age, sex and prevalence and severity of ulcers was statistically assessed.

Prevalence of gastric ulceration in the group of horses examined was $62.96 \%$. Twenty horses (37.04\%) had physiological findings on gastric mucosa (ulcer score 0$), 16$ horses $(29.6 \%)$ had mild changes of gastric mucosa (ulcer score 1$), 14$ horses $(25.9 \%)$ had gastric ulcer score of grade 2 and 4 horses $(7.4 \%)$ had gastric ulcer score of grade 3 . None of the horses $(0 \%)$ had signs of the most severe gastric ulceration (ulcer score 4). There was found neither association between age or sex and prevalence of ulcers nor association between age or sex and severity of gastric ulcers.

From the results we conclude that gastric ulcers are common in Standardbred racehorses in Czech Republic. Prevalence and severity of gastric ulcer does not depend on age and sex of horses.
\end{abstract}

Gastric ulcer, prevalence, age, sex, training, standardbred, racehorse, Czech Republic

Erosion and ulceration of gastric mucosa (equine gastric ulcer syndrome - EGUS) is a common finding in racehorses. According to various authors, prevalence of the disease varies from 55\% to 100\% (Hammond et al. 1986; Murray et al. 1989; Johnson et al.1994; Vatistas et al. 1994; Murray et al. 1996; Orsini et al. 1997; Vatistas et al. 1999; McClure et al. 1999). Although the aetiology of this disease is not completely clear yet, stress is considered important in the aetiologic factor. Proposed stress factors include stall confinement, high-grain diet, intermittent feeding (specifically, withholding feed before exercise), intensive exercise (especially endurance training) and racing (Murray et al. 1996; McClure et al. 1999; Vatistas et al. 1999; Murray 1999). Contrary to common belief, administration of nonsteroidal anti-inflammatory drugs appears to have little impact on the development of EGUS (Murray et al. 1998; Vatistas et al. 1994; Murray et al. 1996). Similar results were found with corticosteroid, ACTH or furosemide administration (Murray et al. 1996), although results of one study revealed an association between furosemide administration and the severity of the ulcers (Vatistas et al. 1994). The significance of Helicobacter pylori infection in gastric ulceration is discussed especially in human medicine (Graham 1989; Smoot and Scott 1992) and it has been neither proven nor excluded in horses yet. No breed predisposition has been found as yet.

Address for correspondence:

MVDr. Barbora Bezděková

Large Animal Clinic, Faculty of Veterinary Medicine

University of Veterinary Amd Pharmaceutical Sciences

Palackého 1-3, 612 ?42 Brno, Czehc Republic
Phone: +420541562380

Fax: + 420541562395

E-mail: bbezdekova@vfu.cz

http://www.vfu.cz/acta-vet/actavet.htm 
According to current knowledge, there is no correlation between age and gastric ulceration in racehorses. Murray et al. (1996) reported similar prevalence of EGUS which varied from $94 \%$ to $97 \%$ among different age groups of Thoroughbred horses (2, 3 and 4 years of age), though the severity of gastric ulcers was slightly increased with age. In a different study, the lowest prevalence of gastric ulceration in 2-year-old racehorses $(70 \%)$ compared with 6year-old horses $(100 \%)$ was reported (Vatistas et al. 1999). However, Murray et al. (1996) found that mean gastric ulcer scores were lower in young horses just beginning race training compared with older horses.

Rabuffo et al. (2002) showed a low correlation between the presence of EGUS in Standardbred horses and their age. In 2-year-old Standardbred racehorses in their first year of racing career, prevalence of EGUS was lower $(80.77 \%)$ than in 3-year-old horses $(88.44 \%)$. This study also showed an association between age and the severity of gastric ulceration. It showed that most lesions in 2-year-old horses were mild (ulcer score, 1), whereas most lesions in older horses were more severe (ulcer score, 2 or 3 ).

In published studies, sex does not appear to be an important risk factor for gastric ulceration. Association between prevalence or severity of gastric ulceration and sex was of low significance in reported studies. The results of sex predisposition to EGUS differ according to various authors (Vatistas et al. 1999; Rabuffo et al. 2002).

Several studies on the prevalence of gastric ulcers in Thoroughbred horses were done (Hammond et al. 1986; Johns on et al. 1994; Murray et al. 1996; Vatistas et al. 1994). However, there are just few studies of EGUS in Standardbred racehorses (Rabuffo et al. 2002). To our knowledge, no published studies have investigated gastric ulceration in individual horse breeds in the Czech Republic.

The objective of our study was:

1. to determine prevalence of gastric ulcer syndrome in 2-year-old or older Standardbred racehorses in the Czech Republic

2. to determine severity of gastric ulcers in monitored population

3. to determine possible association between age and occurrence of EGUS

4. to determine possible association between age and severity of EGUS

5. to determine possible association between sex and occurrence of EGUS

6. to determine possible association between sex and severity of EGUS

Examined horses

\section{Materials and Methods}

Fifty four Standardbred racehorses engaged in routine training and racing were selected for this study. The horses were stalled at 5 trainers. All horses were 2-year-old or older Standardbred racehorses in active race training for at least six months. Age of monitored horses varied from 2 to 11 years. There were 7 two-year-old (12.96\%), 11 threeyear-old $(20.37 \%), 9$ four-year old $(16.67 \%), 4$ five-year-old $(7.41 \%), 9$ six-year-old $(16.67 \%), 1$ seven-year-old $(1.85 \%), 3$ eight-year-old $(5.56 \%), 2$ nine-year-old $(3.70 \%), 4$ ten-year-old $(7.41 \%)$, and 4 eleven-year-old $(7.41 \%)$ Standardbred horses in the monitored group. The examined horses were grouped by sex: males ( 3 horses; $5.6 \%$ ), females ( 21 horses; $38.9 \%$ ), and castrated males [geldings] (30 horses; $55.6 \%)$. All horses were examined within the first 10 days after the end of racing season which finishes in the first half of November in the Czech Republic.

\footnotetext{
Examination procedure

Before each gastroscopic examination, food was withheld from each horse for 12 to 16 hours and free access to water was allowed. The horses were sedated with xylazine $(0.3 / 0.5 \mathrm{mg} / \mathrm{kg} \mathrm{IV})$ and the gastric and esophageal mucosa was examined using a $13-\mathrm{mm}$-diameter, $3.3-\mathrm{m}$ flexible videoendoscope (Dr. Fritz ${ }^{\mathrm{TM}}$ ). Thorough examination included viewing of the squamous epithelium (nonglandular mucosa), margo plicatus, proximal part of the glandular mucosa and cardia. Pyloric region was not routinely examined because of the presence of fluid residue and gastric peristalsis. An adapted gastric ulcer severity scoring system by Nadeau et al. (2002) was used. Lesions were scored on scale $0-4$.

0 - normal mucosa (no lesions)

1 - hyperaemia or hyperceratosis of mucosa or less than 5 small single lesions
} 
2 - diffuse damage of mucosa, multifocal lesions with or without hyperkeratosis, more than 5 lesions, no haemorrhage

3 - multifocal lesions with loss of surface epithelium and hypertrophic margins, more than 10 lesions, diffuse damage

4 - diffuse ulceration of mucosa, loss of margo plicatus continuity, with or without haemorrhage

Statistical analyses

A database was made by use of obtained anamnesis and examination results. Prevalence of EGUS was derived from data in whole population of monitored horses and in individual age and sex categories. Furthermore, severity of ulceration was evaluated in individual age and sex groups. The obtained results were expressed in percentage. The obtained data was statisticaly analysed using $\chi^{2}$ test and its modifications for low periodicity (Fischer's test, G-test) and by use of non-parametric tests (Wilcoxon test, Steel-Dwass test). Commercially available software (Excel, KyPlot) and online data analysis available on Internet were used for statistical analyses.

\section{Results}

1. The overall prevalence of gastric ulceration in monitored Standardbred racehorses in the Czech Republic was $62.96 \%$ (Table 1).

Table 1. Distribution (No. [\%]) of individual age droups in monitored population of Standardbred racehorses; distribution (No. [\%]) of horses with gastric ulcers in individual age groups; overall occurrence of EGUS severity scores in monitored population by age

\begin{tabular}{|c|c|c|c|c|c|c|c|}
\hline Age & No. (\%) of horses & No. (\%) of EGUS positive & \multicolumn{5}{|c|}{ EGUS score } \\
\hline & & & $\mathbf{0}$ & $\mathbf{1}$ & $\mathbf{2}$ & $\mathbf{3}$ & $\mathbf{4}$ \\
\hline 2 & $7(12.76 \%)$ & $3(42.86 \%)$ & 4 & 3 & 0 & 0 & 0 \\
\hline 3 & $11(20.37 \%)$ & $6(54.55 \%)$ & 5 & 4 & 2 & 0 & 0 \\
\hline 4 & $9(16.67 \%)$ & $7(77.78 \%)$ & 2 & 1 & 5 & 1 & 0 \\
\hline 5 & $4(7.41 \%)$ & $3(75.00 \%)$ & 1 & 1 & 1 & 1 & 0 \\
\hline 6 & $9(16.67 \%)$ & $6(66.67 \%)$ & 3 & 1 & 4 & 1 & 0 \\
\hline 7 & $1(1.85 \%)$ & $0(0.00 \%)$ & 1 & 0 & 0 & 0 & 0 \\
\hline 8 & $3(5.56 \%)$ & $2(66.67 \%)$ & 1 & 1 & 1 & 0 & 0 \\
\hline 9 & $2(3.70 \%)$ & $2(100 \%)$ & 0 & 2 & 0 & 0 & 0 \\
\hline 10 & $4(7.41 \%)$ & $4(100 \%)$ & 0 & 2 & 1 & 1 & 0 \\
\hline 11 & $4(7.41 \%)$ & $1(25.00 \%)$ & 3 & 1 & 0 & 0 & 0 \\
\hline Total & $54(100 \%)$ & $34(62.96 \%)$ & 20 & 16 & 14 & 4 & 0 \\
\hline
\end{tabular}

2. Of 54 horses, $20(37.0 \%)$ horses had physiological findings on gastric mucosa (ulcer score, 0$), 16(29.6 \%)$ horses had mild changes of gastric mucosa (ulcer score, 1$), 14$ $(25.9 \%)$ horses had gastric ulcer score of 2 and $4(7.4 \%)$ horses had gastric ulcer score of 3 . No horses $(0 \%)$ had signs of the most severe gastric ulceration, the score of 4 (Table 1).

3. Distribution of gastric ulcers (No [\%] of horses) among Standardbred racehorses is shown in Table 1. There was no significant correllation between age and gastric ulcer occurrence in monitored population.

4. Gastric ulceration severity score in age groups is reported in Table 1. There was no significant difference in EGUS severity among the age groups.

5. Occurrence of EGUS in individual sex groups is shown in Table 2. There was no significant difference in gastric ulcer occurrence among sex groups.

6. Gastric ulceration severity scores in sex groups are shown in Table 2. Among the sex groups, difference in gastric ulcer severity was not significant. 
Table 2. Distribution (No. [\%]) of individual sex groups in monitored population of Standardbred racehorses; distribution (No. [\%]) of horses with gastric ulcers in individual sex groups; overall occurrence of EGUS severity scores by sex

\begin{tabular}{|l|c|c|c|c|c|c|c|}
\hline Sex & No. (\%) of & No. (\%) of EGUS & \multicolumn{5}{|c|}{ EGUS severity } \\
\hline & & & $\mathbf{0}$ & $\mathbf{1}$ & $\mathbf{2}$ & $\mathbf{3}$ & $\mathbf{4}$ \\
\hline Females & $21(38.9 \%)$ & $16(76.19 \%)$ & 5 & 4 & 10 & 2 & 0 \\
\hline Geldings & $30(55.6 \%)$ & $18(60.00 \%)$ & 12 & 12 & 4 & 2 & 0 \\
\hline Stallions & $3(5.6 \%)$ & $0(0.00 \%)$ & 3 & 0 & 0 & 0 & 0 \\
\hline Total & $54(100 \%)$ & $34(62.96 \%)$ & 20 & 16 & 14 & 4 & 0 \\
\hline
\end{tabular}

\section{Discussion}

Prevalence of equine gastric ulcer syndrome in Standardbred racehorses in this study was $63 \%$. Our results are consistent with the studies of gastric ulceration occurrence in Thoroughbred racehorses in training reported by Murray et al. (1996), Murray (1997) or Orsini and Pipers (1997). The last mentioned authors monitored prevalence of EGUS in Thoroughbred racehorses before beginning of training and racing $(28 \%)$ and in same horses in high intensity training $(63 \%)$.

Few studies monitor prevalence of EGUS in Standardbred horses. Rabuffo et al. (2002) reported $89 \%$ prevalence of EGUS in a large group of Standardbred racehorses in training. The difference in occurrence of gastroscopicaly evident gastric erosions in racehorses in the Czech Republic and in Rabuffo's study is supposingly due to a number of horses in active race training. Criteria for selection among horses in Rabuffo's study involved high intensity in race training in all examined Standardbred horses. Criteria for selection among horses in our study was a minimum of 6 months of active race training without considering training intensity.

Number of horses in our study is in correllation with the number of all Standardbred horses in race training in the Czech republic (243 horses, anonymous author, 2003) at the time of gastroscopic examination of horses selected for our study.

Complete examination of squamous epithelium of gastric mucosa was possible, but it was not possible to fully evaluate the glandular part of stomach. Gastroscopic examination in most studies is limited to squamous epithelium of gastric mucosa (Murray et al.1996; Rabuffo et al. 2002). Gastric mucosa examination procedure is limited with the length of endoscope and feed in the stomach. Despite $6-12$ hours of fasting prior the gastroscopy and gas insufflation, gastric fluid and feed is remaining in the stomach which disables thorough examination of glandular mucosa and pylorus. Andrews et al. (2002) reported that intravital gastroscopy is unable to visualize all macroscopic changes of equine gastric mucosa. In this study, gastroscopic findings of gastric ulceration were compared with pathoanatomical examination of gastric mucosa in same horses. Our experience corresponds with these results.

Undoubtedly, most changes are localized in the squamous part of gastric mucosa (S and in et al.2000). Consequently, it is assumed that the glandular part of the equine stomach is more resistant to damage by gastric juice if compared with other species including man (Murray 1997). Changes in glandular mucosa are very often accompanied with NSAIDs administration (Murray et al. 1996).

For objective evaluation of gastroscopic findings in examined horses a 4-grade scoring system of gastric ulcers was used ( $\mathrm{Nadeau}$ et al. 2000). This system appears to be suitable for evaluation of the nonglandular part of gastric mucosa and is widely used. Our results of gastric ulceration occurrence is similar to results obtained in a group of Standardbred racehorses without clinical signs of gastric ulceration reported by Rabuffo (2002). 
The statistics of individual gastric ulceration severity scores is shown in Table 1. Contrary to Rabuffo et al. (2002), we noticed higher occurrence of horses with no findings of gastric ulceration in our study. Concerning ethiopathogenesis of this disease, we suppose that this is due to less intensive training of horses enrolled in our study. In comparison with our results, there was a higher occurrence of more severe gastric ulcer scores reported in Thoroughbred racehorses (Murray et al. 1996).

Several authors studied the association between occurrence of gastric ulcers and the age of horses (Hammond et al. 1986; Murray et al. 1996; Vatistas et al. 1999; Rabuffo et al. 2002) but significant association between age and EGUS occurrence has not yet been seen. Rabuffo et al. (2002) reported higher severity scores of gastric ulceration in 3-yearold, than in 2-year-old Standardbred horses, though this difference was not significant. In this study, the influence of the time spent in race training and training intensity on the gastric ulceration occurrence in older horses is expected. In a former study, Hammond et al. (1986) proved a high association between pathomorphological findings in horses immediately after finishing their racing career as well as in horses at least one month after finishing race training. Association between age and gastric ulcers was not proven in this study (Hammond et al. 1986). We also could not confirm any significant association between the age of horses and EGUS occurrence, or its severity in our study.

In reported studies, there was no association seen between EGUS and sex. However, in some studies a difference in the occurrence of gastric ulcers between stallions and geldings was seen, but in most of the studies castrated and intact males were in the same monitored groups. In more recent publications prevalence of gastric ulcer syndrome ranges from geldings $(94 \%)$ to stallions $(78 \%)$ and females $(82 \%)$ (Vatistas et al. 1999). Rabuffo et al. (2002) proved a predisposition to gastric ulcers in geldings in comparison with stallions and females in Standardbred racehorses in the United States. In this study a sex-associated insufficient production of epidermal growth factor by the salivary glands in geldings and castrated females, which has a potent antiulcer effect, was considered as possible mechanism (Rabuffo et al. 2002). We did not find a significant association between sex and gastric ulcer occurrence or severity. Therefore, our results are similar to cited authors. Influence by low numbers of examined horses in particular sex groups is possible.

In our opinion, character of race training intensity in individual horses is influenced with not only the physical condition but also with the psycological condition of the animal and means a source stress which is individual in each horse. The stress syndrome is associated with release of endogenous corticosteroids which play an important role in ethiopathogenesis of gastric ulceration (Furr et al. 1992). Predisposition to EGUS in easily excited, sanguinic horses can be expected on the same principle.

In conclusion, gastric ulcer syndrome in horses in the Czech Republic was studied in this work. In racehorses, gastroscopy in terrain was performed, results and anamnestic data were statisticaly analysed. Occurrence and severity of gastric ulcers in Standardbred racehorses is corresponding with reported studies. Association between the occurrence of gastric ulceration and the age or sex of monitored horses was not found. In our opinion, race training and race management play an important role in ethiopathogenesis of the disease. The received results on gastric ulcer syndrome in the Czech Republic correspond with reported studies in other countries.

\section{Prevalence syndromu gastrické ulcerace u klusáků v České republice}

Cílem studie bylo stanovení prevalence a závažnosti syndromu gastroduodenální ulcerace u dostihových klusáků v tréninku v České republice a její př́ípadné závislosti na věku a pohlaví. Pro studii bylo využito 54 dostihových klusáků. Každý z koní ve 
sledované skupině byl podroben gastroskopickému vyšetření a byly zaznamenány jeho anamnestické údaje.

Slizniční ulcerace byly odstupňovány od stupně 0 (normální sliznice, žádné léze) do stupně 4 (difúzní slizniční ulcerace, ztráta kontinuity margo plicatus, s krvácením nebo bez). Byla statisticky zhodnocena asociace mezi věkem, pohlavím a prevalencí a stupněm závažnosti gastrických ulcerací.

Prevalence žaludečních ulcerací u koní ve sledované skupině byla 62,96 \%. Z celé populace padesáti čtyř koní mělo dvacet koní $(37,0 \%)$ fyziologický nález na vyšetřené žaludeční sliznici (stupeň závažnosti EGUS - 0). Šestnáct koní (29,6\%) mělo lehké změny žaludeční sliznice klasifikované jako stupeň 1, čtrnáct klusáků $(25,9 \%)$ vykazovalo stupeň poškození žaludeční sliznice 2 a čtyři koně $(7,4 \%)$ vykazovali stupeň závažnosti 3 . U žádného z jedinců sledované populace klusáků nebyl zjištěn nejzávažnější čtvrtý stupeň vředové choroby $(0 \%)$. Ve sledované skupině koní nebyla nalezena asociace mezi věkem, pohlavím a prevalencí žaludečních ulcerací. Zároveň nebyla zjištěna statisticky významná souvislost ani mezi věkem, pohlavím a stupněm závažnosti syndromu. Závěrem lze poznamenat, že syndrom gastroduodenální ulcerace u koní je častým onemocněním a není závislý na věku ani pohlaví.

\section{Acknowledgements}

This study was supported by Internal Grant Agency of the University of Veterinary and Pharmaceutical Sciences Brno, No. 9/2003/ FVL.

\section{References}

ANONYMUS 2004: Věstník České klusácké asociace č.1, ČKA, Praha, LXIV: 34-36

ANDREWS, FM, REINEMEYER, CR, MCCRACKEN, MD, BLACKFORD, JT, NADEAU, JA, SAABYE, L, SOTELL, M, SAXTON, A 2002: Comparison of endoscopic, necropsy and histology scoring of equine gastric ulcers. Equine Vet J Jul 34: 475-478

FURR, MO, MURRAY, M, FERGUSON, DC 1992: The effects of stress on gastric ulceration, T3, T4, reverse T3 and cortisol in neonatal foals. Equine Vet J 24: 37-40

GRAHAM, DY 1989: Campylobacter pylori and peptic ulcer disease. Gastroenterology 96: 615

HAMMOND, CJ, MASON, DK, WATKINS, KL 1986: Gastric ulceration in mature Thoroughbred horses. Equine Vet J 18: 284-287

JOHNSON, B, CARLSON, GP, VATISTAS, N, SNYDER, JR, LLOYD, K, KOOBS, J 1994: Investigation of the number and location of gastric ulcerations in horses in race training submitted to the Kalifornia racehorse postmortem program. In Proceedings: Am Assoc Equine Pract: 123-124

LORENZO, M, BURROW, JA, MERRIT, AM 2001: Barostatic evaluation of the effect of exercise on the equine proximal stomach. Gastroenterology 120: A149-A15

MURRAY, MJ, GRODINSKI, C, ANDERSON, CW, RADUE, PF, SCHMIDT, GR 1989: Gastric ulcers in horses: a comparison of endoskopic findings in horses with and without clinical signs. Equine Vet J 7: 68-72

MURRAY, MJ, SCHUSSER, G 1992: Application of gastric pH-metry in horses: measurement of 24 hour gastric $\mathrm{pH}$ in horses fed, fasted, and treated with ranitidine. J Vet Intern Med 6: 133

MURRAY, MJ, SCHUSSER, GF, PIPERS, FS, GROSS, SJ 1996: Factors associated with Gastric lesions in Thouroughbred racehorses. Equine Vet J 28: 368-374

MURRAY, MJ 1997: Gastroduodenal ulceration. In: Current Therapy in Equine Medicine, 4th edn, Ed: N.E. Robinson: 191-197

MURRAY, MJ 1999: Pathophysiology of peptic disorders in foals and horses: a review. Equine Vet J Suppl 29: 14-18

MCCLURE, SR, GLICKMAN, LT, GLICKMAN, NW 1999: Prevalence of Gastric ulcers in show horses. J Am Vet Med Assoc 215: 1130-1133

NADEAU, JA, ANDREWS, FM, MATJES, AG, ARGENZIO, RA, BLACKFORD, JT, SOHTELL, M, SAXTON, AM 2000: Evaluation of diet as a cause of Gastric ulcers in horses. Am J Vet Res 61: 784-790

ORSINI, JA, PIPERS, FS 1997: Endoscopic evaluation of the relationship between training, racing, and gastric ulcers. Vet Surg 26: 424

RABUFFO, TS, ORSINI, JA, SULLIVAN, E, ENGILES, J, NORMAN, T, BOSTON, R 2002: Associations between age or sex and prevalence of Gastric ulceration in Standardbred racehorses in training. J Am Vet Med Assoc 221: 1156-1159

SANDIN, A, SKIDELL, J, HAGGSTORM, J, NILSSON, G 2000: Postmortem findings of gastric ulcers in Swedish horses older than age one year: a retrospective study of 3715 horses (1924-1996). Equine Vet J 32: $36-42$ 
SMOOT, DT, SCOTT, VF 1992: The role of Helicobacter pylori in the pathogenesis of acid-peptic disease. J Assoc Acad Minor Phys 3: 46-49

VATISTAS, NJ, SNYDER, JR, CARLSON, G, JOHNSON, B, ARTHUR, RM, THURMOND, M, ZHOU, H, LLOYD, KL 1994: Epidemiological study of Gastric ulceration in the Thoroughbred race horse: 202 horses (1992-1993). In Proceedings: Am Assoc Equine Pract: 125-126

VATISTAS, NJ, SNYDER, JR, CARLSON, G, JOHNSON, B, ARTHUR, RM, THURMOND, M, ZHOU, H, LLOYD, KL 1999: Gross-sectional study of Gastric ulcer of the squamous mucosa in Thoroughbred racehorses. Equine Vet J Suppl 29: 34-39

VATISTAS, NJ, SIFFERMAN, RL, HOLSTE, J, COX, JL, PINALTO, G, SCHULZ, KT 1999: Induction and maintenance of Gastric ulceration in horses in simulated race training. Equine Vet J Suppl 29: 40-44 